\title{
TRANSFORMATIVE EDUCATION AS A DIALECTIC OF INDONESIAN CULTURE AND MODERN CULTURE
}

\author{
Saefur Rochmat \\ Jurusan Pendidikan Sejarah FIS, UNY \\ e-mail: saefur_rochmat@uny.ac.id
}

\begin{abstract}
Indonesia has being an independent state more than 73 year, but it is not yet a modern state. It is due to a lack of continuity between Indonesian culture (in the forms of local cultures and religions) and modern culture. National culture, in the form of Pancasila state, is not similar to the original Indonesian culture as it is a mix of Indonesian culture and modern culture. This article is to elaborate transformative education which will synergize Indonesian culture and modern culture. This article is a kind of qualitative research, using observation and literature study methods. It focuses on the immaterial aspects of culture, namely supra-structure of both Indonesian culture and the modern one. Curriculum 2013 Revised that discards religious skills from all subjects, except Religious Education and Civic Education, reflects that government has not yet formulated clearly the national education system. National education should be transformative that enables to synergize the Indonesian culture to the modern one.
\end{abstract}

Keywords: Indonesian culture, modern culture, religious skills, Pancasila.

\section{PENDIDIKAN TRANSFORMATIF SEBAGAI DIALEKTIKA KEBUDAYAAN ASLI DENGAN KEBUDAYAAN MODERN}

\begin{abstract}
Abstrak: Setelah merdeka lebih 73 tahun, Indonesia masih belum menjadi negara modern. Hal itu terjadi karena adanya kesenjangan antara kebudayaan lama dengan kebudayaan modern. Kebudayaan nasional dalam bentuk kebudayaan Pancasila tidak sepenuhnya merupakan kelanjutan kebudayaan asli sehingga Indonesia harus melakukan transformasi budaya. Artikel ini akan membahas pendidikan transformatif, yang akan mendialektikakan kebudayaan asli dengan kebudayaan modern. Artikel ini merupakan hasil penelitian kualitatif, yang dilakukan dengan metode observasi dan studi pustaka. Penelitian ditekankan pada aspek immaterial (suprastruktur), yang menjadi fondasi bagi struktur kebudayaan, baik dalam kebudayaan Indonesia maupun kebudayaan modern. Pendidikan transformatif merupakan pendidikan yang mampu mensinergikan suprastruktur kebudayaan asli (kebudayaan daerah dan agama) dengan suprasturktur kebudayanaan modern. Aspek suprastruktur kebudayaan asli tercermin dalam sila ke-1 yang bersifat religius, sedangkan aspek suprastruktur kebudayaan modern tercermin dalam sila ke-2, 3, 4, dan 5 yang sifatnya rasional. Kedua karakteristik ilmu itu harus menyatu dalam materi pelajaran yang diajarkan di sekolah, yang tercermin dalam religious skills.
\end{abstract}

Kata kunci: kebudayaan asli, kebudayaan modern, religious skills, Pancasila.

\section{PENDAHULUAN}

Setelah merdeka lebih 73 tahun, suatu kurun waktu yang sudah cukup lama, Indonesia belum menjadi sebuah negara yang modern, yang $40 \%$ Pendapatan Domestik Bruto berasal dari sektor industri dan sekarang ini, Indonesia baru memiliki PDB sektor industri sebesar 18\% (Bappenas, 2018:42). Hal itu terjadi karena Indonesia mengalami kendala dalam melakukan transformasi budaya yang memungkinkan bagi keberhasilan proses modernisasi. Yang saya maksudkan dengan kebudayaan di sini adalah kebudayaan dalam arti luas, bukan hanya sekedar kesenian, namun keseluruhan elemen dalam suatu peradaban. Menurut Koentjaraningrat ada 7 elemen kebudayaan, yaitu sistem religi, sistem pengetahuan, sistem bahasa, sistem kesenian, sistem sosial, sistem ekonomi, dan sistem teknologi (Koentjaraningrat, 1988).

Indonesia mengalami kendala transformasi ketujuh elemen kebudayaan menuju negara modern. Memang tingkat hambatan transformasi dalam ketujuh elemen itu tidak sama. Untuk keperluan analisis, saya mengklasifikasikan ele- 
men kebudayaan menjadi dua. Kedua elemen pertama dinamakan aspek immaterial kebudayaan dan lima elemen selanjutnya dinamakan aspek material kebudayaan. Aspek immaterial memiliki peranan penting bagi keberhasilan transformasi dalam aspek material kebudayaan. (Jameson, 2002: 77). Aspek immaterial kebudayaan, sebagai inti dari suatu kebudayaan, dan dikenal dengan istilah supra-struktur dalam analisis Marxisme merupakan fondasi bagi bangunan struktur material kebudayaan, di samping berfungsi memberi makna atau nilai terhadap kehidupan (Selva, Domenech, Gash, 2017:1-3).

Kebudayaan nasional dalam bentuk kebudayaan Pancasila tidak sepenuhnya merupakan kelanjutan dari kebudayaan asli Indonesia. Kebudayaan Pancasila merupakan perpaduan kebudayaan asli (kebudayaan daerah dan agama, khususnya Islam) dengan kebudayaan modern. Dalam pengertian ini, kebudayaan asli tercermin dalam sila ke-1 Pancasila, yang merupakan aspek supra-struktur dari kebudayaan nasional yang akan dibangun. Sila ke-2, 3, 4, dan 5 Pancasila merupakan cerminan kebudayaan modern, sebagai pengembangan pengetahuan yang didasarkan pada akal. Dengan demikian, bentuk negara Pancasila bersifat semi sekuler karena agama (sila ke-1) memiliki peran dalam sektor publik, walaupun dalam bentuk nilai-nilai universal. Jelas hal ini berbeda dengan peradaban Barat yang meminggirkan agama ke dalam sektor privat. Sebagai konsekuensinya, hubungan agama (khsusnya Islam) dengan negara bersifat saling memberi legitimasi (Rochmat, 2014). Atas dasar itu, Acac (2015) menilai secara tepat bahwa Pancasila merupakan bentuk modern dari penerapan Syari'ah.

Indonesia sudah mengadopsi kemajuan peradaban Barat dalam kelima aspek material kebudayaan, namun sampai saat ini Indonesia belum berhasil menjadi negara modern. Hal itu terjadi karena aspek immaterial kebudayaan asli (kebudayaan daerah dan agama) belum memberikan justifikasi terhadap kebudayaan modern sehingga rakyat belum menerima kebudayaan modern secara tulus (Selva, Domenech, and Gash, 2017:3). Untuk keperluan itu, pendidikan transformatif memiliki peranan penting bagi upaya menjembatani kebudayaan asli dengan kebudayaan modern. Pendidikan transformatif mengajarkan materi pendidikan modern yang dimaknai dari sudut pandang supra-struktur kebudayaan asli Indonesia. Dengan kalimat lain, faktor immaterial kebudayaan asli memberikan justifikasi terhadap kebudayaan modern (Jameson, 2002:77).

Indonesia belum menjadi negara modern juga disebabkan Indonesia mengambil kebudayaan modern setengah hati. Indonesia cenderung mengadopsi aspek material dari kebudayaan Barat dan mengabaikan aspek immaterial kebudayaan Barat yang menjadi landasan dan juga konteks bagi produk kebudayaan Barat. Kebudayaan Barat menekankan pada akal sebagai alat untuk mencapai kebenaran dan karenanya mengembangkan prinsip rasionalitas, prinsip checks and balances (saling kontrol), yang akan melahirkan keseimbangan dalam masyarakat (Ladenburg, 2007:46). Dengan demikian, pengetahuan kita tentang aspek material kebudayaan Barat tidak diimbangi oleh aspek immaterial kebudayaan Barat yang menjadi konteks bagi produk material kebudayaan Barat.

Sebenarnya waktu 50 tahun merupakan suatu waktu yang cukup untuk menjadi negara maju bila suatu negara melakukan modernisasi sesuai dengan landasan budayanya dan juga prinsip-prinsip immaterial kebudayaan Barat. Dalam hal ini landasan filosofis yang operasional memiliki peranan menentukan dalam proses modernisasi. Contoh, Otto von Bismarck berhasil menyatukan German pada tahun 1871 dan kemudian pada tahun 1911 berani mengobarkan Perang Dunia I dan sekaligus menjadi negara paling maju di Eropa daratan. Contoh lainnya adalah Jepang yang memodernisasi negaranya sejak Restorasi Meiji tahun 1868 dan pada tahun 1904 Jepang berhasil mengalahkan negara kulit putih Rusia. Contoh lainnya lagi adalah Amerika Serikat yang mengikrarkan politik luar negeri outward looking pada tahun 1896, menjadi negara super power pada tahun 1945.

Memang Indonesia bukan satu-satunya negara yang gagal menjadi negara maju dalam waktu yang cukup lama. Negara-negara yang mayoritas penduduknya Muslim juga gagal mengantarkan negaranya menjadi suatu negara yang maju. Brunei Darussalam dan Arab Saudi memiliki pendapatan per kapita yang sangat tinggi, namun mereka mendapatkannya dari hasil sumber daya alam (SDA) dan bukan dari hasil pengembangan teknologi modern. Nampaknya negara-negara yang mayoritas penduduknya 
Muslim memiliki kendala social capital (modal sosial) dalam mewujudkan sebuah negara yang modern. Contoh modal sosial seperti demokrasi, toleransi, tolong-menolong, budaya antri, Hak Asasi Manusia (HAM) dan lain-lain (Foroutan, 2013:1-2). Modal sosial (social capital) sangat penting bagi terwujudnya solidaritas sosial (solidarity), yang memungkin berbagai kekuatan sosial-politik yang ada untuk berkompetisi secara fair. Muslim cenderung menekankan pada penerapan ajaran-ajaran dalam Rukun Iman dan Rukun Islam, yang merupakan jenis ibadah ritual (ibadah mahdlah) dan kurang mengembangkan ajaran-ajaran sosial dalam Islam, yang dikategorikan sebagai Rukun Sosial (Rochmat, 2014:326). Padahal, ajaran-ajaran sosial dalam Islam sangat banyak sekali dan justru ajaranajaran sosial inilah yang menghandarkan negaranegara menjadi negara industri.

\section{METODE}

Artikel ini merupakan hasil penelitian kualitatif, yang fokusnya lebih pada interpretasi terhadap data agar didapatkan penjelasan yang mendalam terhadap suatu fenomena yang diamati. Adapun fenomena yang diteliti berkaitan dengan proses modernisasi di Indonesia yang mengalami hambatan. Data diperoleh dari studi pustaka dan observasi terhadap proses modernisasi di Indonesia. Data yang diamati baik berupa data kuantitatif maupun data kualitatif. Data diperoleh dari berbagai sumber, seperti website, buku, dokumen, dan observasi. Data memegang peranan penting bagi pemahaman penulis terhadap konteks yang menjadi landasan bagi proses modernisasi itu. Sebenarnya kebudayaan merupakan konteks yang menentukan sukses tidaknya proses modernisasi, baik unsur kebudayaan yang berwujud material maupun yang berujud immaterial. Kesuksesan proses modernisasi ditentukan oleh sejauhmana ada kontinyuitas dari kebudayaan lama ke kebudayaan modern. Kontinyuitas ini berkaitan dengan proses transformasi, yang mana pendidikan memiliki peranan penting. Dengan begitu artikel ini menitikberatkan pada transformasi aspek immaterial kebudayaan, khususnya keterkaitan kebudayaan Indonesia lama dengan kebudayaan modern dan keterkaitan pendidikan Indonesia lama dengan pendidikan modern.

\section{HASIL DAN PEMBAHASAN Hasil}

Indonesia belum menjadi negara modern setelah merdeka 73 tahun karena modernisasi belum benar-benar dilakukan selaras dengan aspek supra-struktur kebudayaan asli Indonesia. Memang kebudayaan nasional, dalam bentuk kebudayaan Pancasila, tidak sepenuhnya kelanjutan dari kebudayaan asli. Kebudayaan Pancasila merupakan campuran kebudayaan asli dengan kebudayaan modern. Kebudayaan asli tercermin dalam sila ke-1 Pancasila, yaitu Ketuhanan Yang Maha Esa. Kebudayaan asli ini mewakili kebudayaan daerah dan agama, khususnya Islam; sedangkan kebudayaan modern tercermin dalam sila ke-2, 3, 4, dan 5. Sila ke-1, sebagai aspek supra-struktur, hendaknya dijadikan landasan dalam memahami sila-sila yang lain. Di sini lain, pembangunan struktur peradaban modern harus juga didasarkan pada pemahaman yang benar terhadap aspek immaterial peradaban modern. Dengan demikian, agen-agen perubahan sosial harus memahami aspek immaterial, baik dalam kebudayaan asli maupun kebudayaan modern (Connor, 2009: 3).

Pemahaman supra-struktur sebagai inti dari suatu kebudayaan dapat merevisi pandangan yang sudah umum bahwa kebudayaan merupakan sistem simbol dan makna. Ada benarnya juga pemahaman kebudayaan sebagai sistem simbol dan makna karena produk kebudayaan, yang tercermin dalam kelima aspek material budaya, memiliki karakteristik yang berbeda dari suatu kebudayaan ke kebudayaan lainnya, yang tentunya memiliki makna tersendiri. Memang adakalanya suatu kebudayaan memiliki simbul tersendiri dengan makna tersendiri pula. Akan tetapi, adakalanya suatu simbul bersifat universal, sehingga bisa menjadi daya perekat antar beberapa kebudayaan. Adakalanya juga simbul yang sama diberi makna berbeda karena masingmasing kebudayaan memiliki aspek immaterial (sistem religi dan sistem pengetahuan) yang berbeda. Hal ini sejalan dengan konsep thick culture yang diperkenalan oleh Geertz (1973: 3-10) dan thick and thin culture oleh Waltzer (1994: 1-20). Yang dimaksud dengan thick culture adalah kebudayaan yang lebih dekat dengan individu dan dalam hal ini agama bisa dikatakan sebagai representasi dari thick culture. Di sis lain, thin culture merupakan kebudayaan yang diperkenalkan kepada individu belakangan, seperti kebudayaan 
nasional (Pancasila). Dengan begitu, individu bisa memiliki multi-identitas: dia bisa menjadi seorang yang religius dan sekaligus Pancasilais.

\section{Pendidikan Transformatif sebagai sinergi aspek supra-struktur kebudayaan asli dan kebudayaan modern}

Pendidikan transformatif belum terjadi seperti yang diharapkan karena tidak banyak agen modernisasi yang memahami aspek suprastruktur dari kebudayaan asli maupun kebudayaan modern. Hal itu nampak dalam dikotomi sistem pendidikan, yaitu Kementerian Pendidikan dan Kebudayaan dan Kementerian Agama. Masing-masing mengembangkan sistem pendidikan yang berbeda. Yang pertama mengembangkan pendidikan modern, yang menekankan pengembangan ketrampilan yang bersumber dari akal. Yang kedua mengembangkan pendidikan agama, yang lebih menekankan pengembangan ketrampilan religius. Memang kedua kementerian sudah mengarahkan terciptanya sistem pendidikan Pancasilais, yang mengembangkan baik ketrampilan berpikir maupun ketrampilan religius. Hal itu nampak dalam kebijakan yang memberikan mata pelajaran agama di sekolah nasional dan sebaliknya kebijakan memberikan mata pelajaran umum (ilmu sekuler) di sekolah yang dikelola oleh Kementerian Agama.

Pendidikan transformatif merupakan bentuk pendidikan yang bisa mensinergikan aspek supra-struktur baik kebudayaan asli maupun kebudayaan modern dalam setiap materi pelajaran. Sila ke-1, yang merupakan aspek immaterial (supra-struktur) kebudayaan asli, hendaknya menjiwai sila-sila yang lain. Sila ke-1 merupakan pencerminan unsur religi dan sistem pengetahuan, sebagaimana dipahami Koentjaraningrat (1988) dalam kategori tujuh elemen kebudayaan. Adapun sila ke-2, 3, 4, dan 5 sebagai produk dari kebudayaan modern harus dipahami dalam konteks supra-struktur kebudayaan modern. Oleh karena itu, pelembagaan strukturstruktur kebudayaan modern, baik dalam aspek sistem sosial, termasuk sistem politiknya; sistem ekonomi, sistem bahasa, sistem kesenian, dan sistem tekonologi tidak boleh dilepaskan dari prinsip-prinsip seperti rasionalitas, keseimbangan (checks and balances), efisiensi, transparan.

\section{Religious Skills sebagai dialektika Ilmu Religius dengan Ilmu Modern}

Pendidikan memiliki peranan penting dalam proses transformasi kebudayaan asli ke kebudayaan modern. Akan tetapi, materi pendidikan di Indonesia belum sepenuhnya bersifat transformatif. Dua kutub ekstrim mata pelajaran, Pendidikan Agama di satu pihak dan Pendidikan Pancasila dan Kewarganegaraan di pihak lain, sepertinya berjalan sendiri-sendiri. Pendidikan agama, khususnya Islam, cenderung mengajarkan aspek identitas agama, seperti tercermin dalam Rukun Iman dan Rukun Islam. Pendidikan Agama kurang menaruh perhatian pada aspek universal agama, seperti tercermin dalam social capital (Rukun Sosial). Aspek universal agama ini merupakan fondasi yang membangun kebudayaan modern. Hal itu terjadi karena guru agama kurang memahami ilmu-ilmu modern. Di lain pihak, guru Pendidikan Pancasila dan Kewarganegaraan yang terdidik di sekolah umum, tidak memahami ilmu-ilmu religius. Oleh karena itu, mereka dalam mengajarkan materi pelajaran tidak mengaitkan dengan keyakinan agama siswa. Akibat lebih lanjut, siswa mempelajari ilmu-ilmu modern dengan tidak sepenuh keyakinan.

\section{Pembahasan}

\section{Pancasila sebagai Dialektika Kebudayaan Indonesia dengan Kebudayaan Modern}

Masalah kebudayaan nasional tidak menjadi kendala bagi Jepang dan karenanya Jepang berhasil memodernisasi negerinya secara cepat. Jepang punya komitmen yang kuat terhadap keyakininannya bahwa pendidikan merupakan kunci bagi kemajuan suatu bangsa. Jepang tidak menghadapi ketegangan yang berarti antara kebudayaan asli yang fokusnya pada agama dengan kebudayaan modern yang salah satunya dimanifestasikan dalam bentuk nasionalisme. Hal ini nampak dalam kontiyuitas sistem penyelenggarakan pendidikan, yang melanjutkan sistem pendidikan yang sudah ada dan tetap diselenggarakan oleh para pemuka agama. Jadi ada kelanjutan antara sistem pendidikan tradisional dengan sistem pendidikan modern. Pemerintah yang berkuasa tidak mengembangkan sistem pendidikan tersendiri. Justru pemerintah membantu mengembangkan sistem pendidikan tradisional yang sudah ada. Mengingat adanya kontinyuitas antara tradisi dan modernisasi, guru 
tidak jarang menyuruh muridnya mengunjungi tempat-tempat ibadah agama Shinto dalam upaya menanamkan semangat nasionalisme.

Bila dibandingkan dengan Jepang, modernisasi Indonesia berjalan lambat karena kita belum berhasil merumuskan kebudayaan nasional yang operasional (Galanter, 1965: 133). Sebenarnya Indonesia sudah merumuskan Pancasila sebagai landasan bagi kebudayaan nasional, namun Pancasila belum sepenuhnya operasional dalam semua aspek kehidupan, baik dalam sistem pendidikan, sistem sosial kemasyarakatan, sistem politik, sistem kebudayaan, sistem ekonomi, dan lain-lain. Hal itu karena Pancasila tidak sepenuhnya kelanjutan kebudayaan asli, namun juga merupakan bentuk adopsi kebudayaan modern. Hal itu dilakukan karena Pancasila merupakan hasil kompromi antar berbagai kekuatan sosial politik yang ada, baik yang berasal dari pendukung kebudayaan Indonesia maupun pendukung kebudayaan modern.

Pancasila merupakan hasil dialektika kebudayaan asli Indonesia (termasuk agama) dengan kebudayaan modern. Sila ke-1 mencerminkan kebudayaan asli Indonsia, sedangkan sila ke-2, ke-3, ke-4, dan ke-5 merupakan manifestasi dari kebudayaan Barat. Sila ke-2 sampai ke-5 bisa dikatakan sebagai ilmu duniawi (ilmu sekuler), yang didasarkan pada akal manusia, sedangkan sila ke-1 sebagai ilmu yang bersifat religious karena didasarkan pada keyakinan manusia yang bersumber dari hati. Dengan kata lain, agama hendaknya dijadikan petunjuk dalam kehidupan duniawi (sekuler), termasuk dalam kehidupan publik di Indonesia (Selva, Domenech, Gash, 2017: 3-4).

Pancasila tidak mengadopsi teori sekulerisasi Barat secara murni, selaras dengan konteks rakyat Indonesia yang bersifat religius. Agama merupakan aspek immaterial kebudayaan Indonesia yang akan memberi makna terhadap aspek material kebudayaan. Peran agama sangat penting karena memberi justifikasi atau legitimasi terhadap aspek material kebudayaan. Akan tetapi, agama sebagai suatu aturan jangan sampai dipolitisasi (agama digunakan sebagai alat politik), karena sejalan dengan prinsip "wasit tidak boleh ikut main dalam pertandingan". Memang agama memiliki peranan dalam sektor publik, tidak seperti di kebudayaan Barat yang meminggirkan peran agama ke ranah privat semata, namun peran agama dalam bentuk nilai- nilai universal, bukan dalam karakternya yang primordial (Acac, 2015).

Kebudayaan nasional memiliki peranan krusial dalam modernisasi karena merupakan konteks berlangsungnya proses modernisasi, namun kebudayaan nasional kita, Pancasila, belum mantap. Hal itu karena Pancasila merupakan hasil kompromi berbagai kekuatan sosial-politik, termasuk kelompok agama. Untuk itu, berbagai kekuatan sosial politik itu harus terus mengembangkan dialog agar paradigma Pancasila bisa operasional dalam kehidupan berbangsa dan bernegara. Berikut penilaian kritis Barnet (1995: vii) terhadap modernisasi di dunia ketiga.

The main problems in the Third World are not, by and large, the absence of technical specialists -countries such as India and Pakistan have these aplenty; ... The main problems are sociological and political problems, the contexts within which apparently "technical" decision are taken [garis miring merupakan penekanan penulis].

Masalah kebudayaan nasional nampak jelas dalam sejarah modern bangsa Indonesia, bahkan sampai sekarang ini. Hal ini nampak dalam dualisme sistem pendidikan, yaitu Departemen Pendidikan dan Kebudayaan, yang mengelola ilmu sekuler dan Departemen Agama yang mengelola ilmu keagamaan. Kedua departemen mengembangkan dua sistem pengetahuan yang berbeda, yaitu modern system of knowledge (dari kebudayaan Barat) dengan religious system of knowledge (dari kebudayaan Indonesia). Hal itu terjadi karena elit politik yang memerintah tidak bisa mentransformasikan religious system of knowledge dengan modern system of knowledge (Burhani, 2017: 330).

Mayoritas elit politik merupakan produk kebudayaan Barat dan mereka berasal dari golongan priyayi (golongan elit tradisional) yang juga telah mencari legitimasi dari Islam. Dalam kenyataannya, kelas priyayi ini kurang berhasil mentransformasikan Islam dengan kebudayaan asli Indonesia, sehingga mereka pun tidak bisa mentransformasikan Islam dengan kebudayaan modern. Penjajah Belanda pun tidak pernah berusaha mentransformasikan kebudayaan kebudayaan Islam) dengan kebudayaan Barat. Mereka berusaha melakukan pendekatan asimilasi kebudayaan lokal dengan kebudayaan Barat, 
yang sekaligus akan memisahkan kelas priyayi dengan kelompok santri (Muslim) (Burhani, 2017: 334).

Mengingat mayoritas elit yang memerintah tidak belajar di lembaga pendidikan tradisional (yang berlandaskan religious system of knowledge), mereka tidak bisa melakukan transformasi sistem pendidikan tradisional ke dalam sistem pendidikan modern. Mereka lalu mengembangkan sistem pendidikan nasional tersendiri, yang berbeda dengan sistem pendidikan di pesantren. Memang kemudian ada usaha untuk saling mendekatkan religious system of knowledge dengan modern system of knowledge dengan cara memberikan pelajaran agama di sekolah umum dan sebaliknya memberikan pelajaran umum di sekolah agama. Apakah kita perlu melebur kedua kementerian itu menjadi satu kementerian saja bila kedua pendekatan itu sudah bisa menyatu? Yang penting bukan peleburan kedua kementerian itu, tetapi kedua kementerian memiliki visi dan misi yang sama untuk menyatukan sistem pengetahuan religius dengan sistem pengetahuan duniawi. Penyatuan kedua kementerian itu bisa melahirkan sikap otoriter karena pejabat yang memerintah menjadi memiliki kekuasaan dan kewenangan yang sangat besar, sehingga hilang prinsip checks and balances, sebagai salah satu ciri aspek immaterial kebudayaan modern (Laver and Shepsle, 1994: 294).

Bila aspek immaterial (khsusunya agama) sudah selaras dengan aspek material dari kebudayaan modern, kita akan bisa melakukan modernsasi secara cepat. Selama ini Muslim melakukan modernisasi dengan setengah hati karena aktivitas yang dilakukan dalam sektor publik seringkali tidak didasarkan pada keyakinan agamanya. Hal itu terjadi karena pendidikan agama cenderung hanya mengajarkan ajaran-ajaran yang termasuk ibadah khusus (mahdlah), belum dikaitkan dengan ajaran-ajaran sosial yang sifatnya umum. Dalam hal ini, Muslim cenderung menjalankan ajaran-ajaran yang tercantum dalam Rukun Iman dan Rukun Islam saja, dan belum ditransformasikan dengan ajaran-ajaran sosial (Rukun Sosial), seperti yang tercantum dalam sila ke-2, ke-3, ke-4, dan ke-5. Akibatnya, mereka mengalami krisis moral dalam kehidupan di sektor publik, yang nampak dalam merebaknya praktek Korupsi, Kolusi, dan Nepotisme (KKN) di negeri Muslim terbesar di dunia (Noy, 2017: 39-41). Penyakit KKN ini disinyalir terjadi karena kita sedang mengalami split identity (kepribadian terbelah) karena aspek immaterial (agama) belum bisa menjelaskan aspek material kehidupan publik, seperti kemanusian, nasionalisme, demokrasi dan keadilan.

Berdasarkan uraian di atas, kebudayaan nasional merupakan faktor kunci bagi keberhasilan pembangunan suatu bangsa. Kebudayaan nasional merupakan identitas bangsa yang digali dari khasanah budaya bangsa. Yang menjadi masalah, Indonesia sebagai suatu negara bangsa (nation state) adalah suatu yang baru, yang secara legal baru diproklamasikan 17 Agustus 1945. Tidak mudah mewujudkan suatu budaya nasional, hal itu memerlukan proses panjang melalui serangkaian komunikasi timbal balik demi terciptanya solidaritas sosial dan akan menghasilkan kesadaran bersama (conscience collective). Kesadaran bersama merupakan moralitas suatu bangsa dan hal itulah yang menjadi pedoman bagi semua komponen bangsa dalam berinteraksi satu dengan lainnya. Bila kesadaran bersama sudah berhasil dirumuskan secara operasional, semua komponen bangsa dapat berpartisipasi secara aktif dalam pembangunan (Bellah, 1973: ix).

Sejalan dengan konsep negara modern yang memisahkan kepemimpinan politik dari kepemimpinan agama, tokoh agama (terutama ulama) berperan sebagai elemen civil society, yang bertugas melakukan checks and balances terhadap negara. Dalam konteks negara Pancasila, peran civil society tidak terbatas pada sektor privat, seperti di Barat yang mengadopsi teori sekulerisasi murni. Tokoh agama bisa memainkan peran di sektor publik, namun mereka hanya memperjuangkan nilai-nilai universal seperti yang tercantum dalan sila ke-2, ke-3, ke-4, dan ke-5. Dengan demikian, agama tidak mendesakan nilai-nilai agama yang sifatnya khusus.

Tidak mudah mewujudkan peran publik agama karena hal ini berkaitan dengan transformasi aspek immaterial (terutama agama) ke dalam kebudayaan modern, baik aspek material maupun immaterialnya. Bila aspek immaterial (terutama agama) belum memberikan justifikasi aktivitas sektor publik, umat beragama akan mengalami kesulitan dalam mengembangkan dialog di antar umat beragama, baik dari kalangan intern umat maupun antar umat beragama. Dialog hendaknya diarahkan untuk merealisasi- 
kan nilai-nilai universal seperti yang tercantum dalam Pancasila. Memang Pancasila memiliki keterbatasan, karena sifatnya sebagai suatu kontrak sosial, sehingga perlu bantuan dari agama maupun budaya lokal dalam mengelaborasikannya secara operasional di masyarakat. Memang agama dan budaya dimaksudkan sebagi sumber nilai! Sedangkan Pancasila sebagai kontrak sosial lebih merupakan suatu kompromi, yang tentunya akan dimaknai sesuai dengan keyakinan masing-masing berdasarkan agama atau budaya yang dianutnya (Abdullah, 2001: 7).

Umat beragama jangan bersaing mengusai alat-alat negara demi mendesakkan ajaran-ajaran khusus agamanya di sektor publik. Penguasaan alat-alat negara oleh suatu kelompok umat beragama tidak mendukung terciptanya negara modern yang demokratis karena urusan politik masuk dalam birokrasi. Bila suatu unit atau instansi birokrasi dikuasai oleh kelompok tertentu, sistem seleksi dan rekrutmen pegawai seringkali mengabaikan prinsip merit.

Ada kelompok-kelompok intern umat beragama (baik dari kalangan Islam, Kristen, Hindu, Budha, dan lain-lain) yang bersaing mendapatkan kedekatan dengan rezim untuk melindungi kepentingan kelompoknya dan menghalangi kepentingan kelompok lainnya. Seharusnya mereka tidak menganggap praktek keagamaan dari kelompok lain sebagai menyimpang dan menganggap praktek keagamaannya sebagai satu-satunya yang paling benar. Hal itu jelas bertentangan dengan prinsip negara modern yang mengakui kelompok-kelompok umat beragama sebagai suatu denominasi dan karenanya mereka harus mengembangkan prinsip toleransi. Hal ini juga bertentangan dengan semangat agama sebagai rahmatan lil 'alamin (rahmat bagi kemanusiaan).

Pemerintah harus membantu pemberdayaan ormas beragama sebagai elemen civil society, apalagi negara Pancasila bukanlah negara sekuler (Acac, 2015: 60-61). Berdasarkan teori politik modern, pemerintah tidak hanya mengembangkan sentralisasi kekuasaan, tetapi juga harus menciptakan mekanisme checks and balances demi tegaknya demokrasi. Dengan demikian antara umat beragama dengan pemerintah saling mengembangkan legitimasi timbal balik (a mutual legitimacy) demi tegaknya prinsip syuro (demokrasi) dan terciptanya kesejahteraan dan keadilan (Laver and Shepsle, 1994: 294).
Selama ini pemerintah belum sepenuhnya membantu umat beragama agar berperan aktif sebagai bagian dari civil society. Ada dua kemungkinan kenapa hal ini terjadi. Pertama, pemerintah ingin mempertahakan kepentingan politiknya. Untuk itu penguasa bisa memainkan politik devide et impera terhadap berbagai kelompok umat beragama. Konsekuensinya, pemerintah yang tidak demokratis bisa tetap bertahan karena adanya kecurigaan sesama umat beragama sehingga kelompok nasionalis maupun non-Muslim cenderung membela penguasa. Kedua, pemerintah khawatir terhadap proses suksesi karena kebudayaan nasional masih belum kokoh. Pemerintah merasakan adanya sebagian umat beragama yang ingin melakukan dominasi dalam kehidupan berbangsa dan bernegara.

Sampai sekarang masih ada kendala bagi semua komponen bangsa berpartisipasi aktif dalam pembangunan karena mereka belum merumuskan landasan filosofis yang operasional. Hal ini berdampak pada kehidupan politik nasional yang labil karena Pancasila ditafsirkan sesuai dengan kepentingan ideologisnya masing-masing. Sebenarnya perbedaan pandangan politik tidak menjadi masalah andaikata semua kelompok sosial politik tidak bersifat ideologis dan bersedia menerapkan prinsip take and give. Kebenaran hendaknya dirumuskan bersama oleh semua komponen bangsa dalam bentuk tindakan bersama yang bermanfaat bagi kemanusiaan. Bukankah konsep kebaikan memiliki ciri-ciri obyektif yang bisa diterima dengan akal sehat.

\section{Religious Skills sebagai dialektika Ilmu Barat (Sekuler) dengan Ilmu Agama}

Pada tahun 2017 pemerintah merevisi Kurikulum 2013 dan pemerintah menghilangkan religious skill dalam semua mata pelajaran di sekolah, kecuali untuk Pendidikan Agama. Dihapusnya religious skill dalam kegiatan belajar mengajar di kelas dapat dipahami bila dalam prakteknya guru hanya mengajak peserta didik berdoa ketika memulai dan mengakhiri pelajaran. Bentuk religious skill yang seperti ini jelas tidak memiliki dampak yang fundamental dalam dunia pendidikan. Bukahkah dalam KTSP 2006 dan kurikulum-kurikulum sebelumnya guru juga selalu memulai dan mengakhiri pelajaran dengan berdoa. Yang dimaksud dengan religious skills adalah kemampuan mengaitkan materi pelajaran dengan nilai-nilai agama yang dianut oleh siswa. 
Hal ini mutlak diperlukan karena apa yang dilakukan dalam kehidupan sehari-hari harus memiliki landasan yang kuat menghujam dalam keyakinan agamanya. Implikasinya, siswa akan menjalani kehidupan sehari-hari berdasarkan keyakinan agama, sehingga semua kegiatan yang dilakukannya diharapkan akan membuahkan hasil yang maksimal. Dengan begitu, dihapusnya religious skills merupakan indikasi Indonesia belum memiliki paradgima sistem pendidikan yang jelas.

Sejalan dengan kebudayaan nasional, sistem pendidikan Indonesia harus berlandaskan pada Pancasila. Paradigma Pancasila bukan paradigma sekuler yang hanya menekankan pada peranan akal dalam pendidikan. Paradigma Pancasila bersifat religious skills, sebagaimana sila ke-1 Pancasila adalah Ketuhanan Yang Maha Esa. Itulah sebabnya Acac (2015) menulis artikel yang berjudul 'Pancasila: a contemporary application of Maqasid al-Syari'ah' (2015). Bukankah sila pertama itu menjiwai sila-sila yang lain? Hal ini berarti agama merupakan suatu paradigma untuk menjalankan Pancasila dalam kehidupan berbangsa dan bernegara. Hal ini juga berarti kaca mata agama senantiasa dipakai ketika kita mempelajari ilmu duniawi, yang sering diberi label ilmu modern atau ilmu sekuler. Sebagai konsekuensinya, pelaksanaan sila ke-2, ke-3, ke-4, dan ke-5 harus dipandu oleh sila ke-1.

Paradigma Pancasila sejalan dengan paradigma agama (dalam hal ini Islam) yang tidak membedakan ilmu agama dengan ilmu duniawi karena semua ilmu harus diabdikan bagi kepentingan Allah, yang berarti berguna bagi kemanusiaan. Ilmu menyatu dengan amal. Ilmu agama berfungsi untuk mengarahkan ilmu duniawi, yang sangat diperlukan dalam kehidup-an di duniawi, agar tidak menjadi bencana bagi kemanusiaan; bukankah membela Allah identik dengan membela kemanusiaan? (Acac, 2015: 70). Dalam hal ini slogan Albert Einstein "ilmu tanpa agama buta dan agama tanpa ilmu lumpuh" menemukan relevansinya. Kemanusiaan merupakan faktor obyektif yang bisa menyatukan ilmu sekuler dengan ilmu religius, dalam artian sebagai peperangan abadi antara kekuatan Tuhan dengan kekuatan setan (Mulkhan, 2001: 20).

Ada kaitan erat antara ilmu (duniawi/ sekuler) yang berdasarkan akal dengan ilmu agama yang berdasarkan hati sehingga pendidikan harus bisa mengaitkan keduanya itu.
Ilmu sekuler mengajarkan kita berpikir logis, sistematis, kritis, kritis, analisis, dan evaluatif (Widyastuti, 2018: 183). Pada tahap evaluatif kita bisa mengaitkan ilmu sekuler dengan ilmu agama dalam rangka memberi makna pada pengetahuan. Dengan demikian, penghapusan religious skills dalam Kurikulum 2013 Revisi terhadap semua mata pelajaran, kecuali mata pelajaran Pendidikan Agama dan mata pelajaran Pendidikan Pancasila dan Kewarganegaraan, merupakan suatu kesalahan. Memang Kurikulum 2013 tetap mempertahankan ketrampilan religius dan ketrampilan sosial dalam Kompetensi Inti-nya, namun guru tidak mengembangkannya dalam perangkat pembelajaran. Hal itu dilakukan dengan pertimbangan untuk mengurangi beban tugas guru. Hal itu jelas suatu kontradiksi. Sebenarnya, guru tidak harus membuat perangkat pembelajaran yang mendetail dari pembuatan RPP sampai pelaksanaan Evaluasi. Yang paling inti dari proses penanaman nilai-nilai religius dan sosial ada pada materi pembelajaran.

Bila buku pelajaran sudah disusun berdasarkan pertimbangan nilai-nilai religius dan sosial, guru tidak perlu menyusun lagi materi pembelajaran. Dengan demikian, pemerintah perlu memastikan buku pelajaran sudah mengembangkan pengetahuan akal dan hati sekaligus. Pendekatan integratif dalam Kurikulum 2013 pra-Revisi sudah benar, namun hal itu belum dibarengi dengan buku paket dari matamata pelajaran yang mampu mengintegrasikan ilmu duniawi dengan ilmu agama.

Adanya kewajiban guru mencantumkan Kompetensi Inti berkaitan dengan ketrampilan religius dan sosial di dalam RPP menunjukkan bahwa guru masih diberi tugas untuk mendidik religious skills dan social skills. Dalam kegiatan belajar mengajar, guru membuka pelajaran dengan berdoa dan juga mendidik nilai-nilai ketrampilan religius dan sosial lainnya. Guru juga menyampaikan nilai-nilai tersebut ketika melakukan refleksi pada bagian penutup. Sebenarnya apa makna refleksi itu? Mengingat belum jelasnya panduan melakukan refleksi, guru seringkali hanya mengutip kata-kata mutiara yang seringkali tidak ada kaitannya dengan materi pelajaran yang diajarkan. Seharusnya refleksi merupakan suatu usaha untuk mengkaitkan ilmu duniawi itu dengan agama yang menjadi sumber nilai. 
Religious skills tidak hanya menjadi beban Pendidikan Agama karena hal itu tidak hanya didapatkan dari pendidikan agama, apalagi pendidikan agama cenderung hanya mengajarkan materi ibadah mahdlah. Religious skills tidak bisa dikuasai siswa bila Pendidikan Agama hanya fokus pengajaran Rukun Iman dan Rukun Islam. Religious skills hanya akan didapatkan bila materi agama dikaitkan dengan ajaran-ajaran sosial (Rukun Sosial), sehingga siswa bisa menjalani kehidupan sehari-hari secara religius. Bukankah ketrampilan religius tidak hanya ketika mereka melakukan ritual ibadah? Jadi, religious skills diperlukan selama 24 jam sehari. Untuk itu pendidikan agama harus diintegrasikan dengan ilmu duniawi. Dengan kata lain, semua materi pelajaran harus dikaitkan dengan keyakinan agama. Untuk itu Pendidikan Agama tidak hanya bersifat normatif, tetapi bersifat kontekstual dengan sistem sosial kemasyarakatan dan ekonomi, termasuk sistem politik. Jadi, guru agama hendaknya mengaitkan ilmu agama dengan ilmu duniawi, yang tercermin dalam Rukun Sosial. Dengan begitu, pendidikan agama mengembangkan pendekatan sosio-kultural, yaitu pendekatan yang mengkaitkan aspek normatif dengan konteks bagi penerapan nilai-nilai agama. Idealnya, baik Kementerian Pendidikan Nasional dan Kementerian Agama berperanan dalam mengharmoniskan pengetahuan agama dan pengetahuan duniawi. (Abdullah, 2001: 7).

Memang Al-Qur'an hanya satu, namun pemahaman terhadapnya tidaklah monolitik karena konteks bagi diterapkannya ajaran-ajaran dan nilai-nilai Islam itu berbeda. Perbedaan konteks harus diketahui siapa saja yang hendak menerapkan Islam dalam kehidupan karena hal itu mengindikasikan adanya perbedaan sistem kebudayaan, termasuk sistem sosial maupun sistem politik. Perbedaan konteks memang harus dipahami dan Allah menyuruh Nabi Muhammad SAW melalui ayat pertamanya iqra (Bacalah!). Ingat, Nabi Muhammad SAW merupakan seorang Nabi yang ummi (tidak dapat membaca). Apa maknanya? Nabi disuruh membaca konteks yang akan digunakan untuk menerapkan ajaranajaran Islam. Implikasinya, dalam suatu agama, misalnya Islam, bisa muncul berbagai kelompok yang mengmbangkan tradisi keagamaan yang berbeda.

Adanya bermacam-macam tradisi keagamaan menunjukkan adanya berbagai systems of knowledge dan fakta bahwa tidak ada kebenaran tunggal dalam urusan agama. Bahkan, dalam ilmu pengetahuan duniawi juga tidak ada kebenaran tunggal karena adanya berbagai macam paradigma yang mengembangkan pendekatan berbeda-beda terhadap suatu obyek ilmu. Implikasinya, "knowledge is not identical to the truth, but it has commitment with the truth' (Saunders, 2004: 164). Mengingat banyak sistem pengetahuan, kita jangan menggunakan pendekatan ideologis dalam kehidupan, yang cenderung melihat kebenaran dari salah satu sudut pandang paradigma (Wahid, 1997: 79-82). Pendekatan ideologis akhirnya melahirkan kebenaran formal berdasarkan sudut pandang tertentu, sehingga kebenaran itu tidak bisa diterima oleh mereka yang mengembangkan paradigma yang berbeda atau pun mereka yang mengembangkan tradisi pemikiran yang berbeda. Bila hal itu dipaksakan, konflik antar-paradigma atau antar-tradisi tidak dapat dihindari. Yang umum terjadi, masing-masing paradigma tidak mau mengembangkan prinsip 'memberi dan menerima' (give and take), yang berguna bagi upaya pencarian kebenaran bersama.

Kompromi berdasarkan pendekatan akal tidak mudah dilakukan karena salah satu sifat dari akal adalah tidak mau rugi. Hal itu karena akal menghasilkan kebenaran yang bersifat material. Akibatnya, tidak jarang akal digunakan secara tidak sewajarnya, seperti memanipulasi (ngakal-ngakali) kebenaran demi terpenuhinya kebutuhan material tertentu. Untuk keperluan itu, para pendukung pendekatan ideologis berkedok pada aturan-aturan formal sebagai alat untuk meyakinkan pihak lain dan pada saat yang bersamaan, mereka menyembunyikan kebenaran yang hakiki demi. Oleh karena itu, mereka cenderung mengembangkan cara-cara kompromi atau negosiasi untuk mempertahankan keuntungan material yang mungkin didapatkannya (Wahid, 1997: 80-82).

Pendekatan ideologis ini sangat mengagungkan peranan akal untuk memecahkan berbagai problem kehidupan. Dalam kenyataannya, ilmu dan teknologi modern tidak dapat mengatasi semua problem kehidupan dan tidak sedikit ilmu dan teknologi memiliki dampak negatif pada suatu masyarakat. Untuk itu, peran akal perlu dilengkapi dengan peran hati dalam usahanya mencari kebenaran. Dengan pertimbangan hati, manusia akan mengembangkan kehidupan 
yang berprinsip pada konsep harmoni karena dia tidak menonjolkan prinsip menangnya sendiri. Dia akan mempertimbangkan hak dan kewajiban pihak lain dalam kehidupan bersama. Dia pun mau memberikan kompensasi bila pihak lain dirugikan. Bahkan, dia bisa membantu pihak lain melakukan transformasi dalam rangka mewujudkan kehidupan yang lebih baik (Wahid, 1997: 79-82).

Pengikut ideologi yang berbeda-beda seringkali berperang satu dengan yang lainnya karena mereka tidak mengembangkan konsep kebenaran dalam konteks timbal balik (relationship). Seperti sudah saya jelaskan di atas bahwa tidak ada kebenaran absolut di dunia ini karena hal ini berkaitan dengan kompleksnya kehidupan yang senantiasa berubah dengan berjalannya waktu dan konteks ruang yang plural. Dalm kenyataanya, kebenaran seringkali tersembunyi dalam fenomena kultural tertentu karena aspek normatif terkait erat dengan peristiwa kultural tertentu. Dengan kata lain, eksistensi kebenaran itu tidak tergantung begitu saja pada pemikiran individu saja, tetapi terkait juga dengan sistem sosial dan budayanya. Implikasinya, konsepsi kebenaran individual harus dinegosiasikan dengan masyarakat sebagai konteksnya (Wahid, 2001: 147-148). Dalam kehidupan, Al-Qur'an melarang kita mengklaim kebenaran sepihak dan memerintahkan kita mengembangkan prinsip koeksistensi antar berbagai kelompok yang berbeda-beda: "Untukmu agamamu dan untukku agamaku (the Qur'an 109:6) (Al-Hillali dan Khan, 2007: 853). Maknanya, masing-masing kelompok dapat meyakini kebenarannya secara absolut karena hakikat kebenaran absolut itu menghendaki sikap instrospeksi kedalam dan tidak menuntut pengakuan pihak luar yang tidak meyakininya (Mufid, 2010: 73-74).

Kebenaran akal bukan satu-satunya realitas kehidupan, karena ada realitas kehidupan lain yang perlu diperhitungkan, yaitu perasaan ketidakpastian dan kehampaan (the feeling of uncertainty and of emptiness). Perasaan tersebut akan mempertajam perasaan kemanusiaan, sehingga dia mau mengalah demi mendapatkan realitas lain yang berada di luar dunia ini. Hal ini akan mengarahkan manusia kepada kesadaran akan Tuhan, satu-satunya yang pasti dan mutlak (the only certain and absolute entity). Implikasinya, pendekatan hati dapat meredam konflik antar sesama manusia yang biasanya dipicu oleh rebutan realitas material di dunia ini (Wahid, 1997: 79-82).

\section{SIMPULAN}

Indonesia belum bisa menjadi negara modern, padahal sudah merdeka 71 tahun. Jepang, Jerman, dan Amerika bisa menjadi negara maju dalam waktu yang singkat, karena mereka sudah memiliki budaya nasional. Indonesia memiliki kendala dalam mewujudkan kebudayaan nasional karena kebudayaan nasional dalam bentuk Pancasila tidak sepenuhnya kontinyuitas dari kebudayaan asli. Sila ke-2, 3, 4, dan 5 diadopsi dari kebudayaan modern, sehingga kita perlu pendidikan transformatif. Memang tidak mudah mensinergikan kebudayaan asli yang religius dengan kebudayaan Barat yang rasional. Hal itu menuntut kemampuan memahami aspek immaterial kebudayaan asli dan sekaligus kebudayaan modern. Akan tetapi, bila pendidikan transformatif ini berhasil, Indonesia bisa menjadi modern dalam waktu cepat dan sekaligus bisa mengatasi krisis peradaban modern.

Penghapusan religious skill dalam Kurikulum Revisi 2013 tidak memiliki landasan filosofis yang kuat karena Pancasila mengamanatkan kepada kita bahwa sila ke-1, Ketuhanan Yang Maha Esa, hendaknya menjiwai sila-sila yang lain. Hal ini berarti bahwa kita hendaknya mengembangkan paradigma yang religious. Mengingat Indonesia tidak menganut model negara sekuler murni, negara harus mendapatkan legitimasi dari agama. Nilai-nilai agama mengarahkan jalannya kehidupan berbangsa dan bernegara. Implikasinya, ilmu sekuler harus dipandang berdasarkan sudut pandang agama yang menekankan pada hati sebagai alat untuk mendapatkan kebenaran. Sejalan dengan itu, materi pendidikan hendaknya bisa menghasilkan religious skills. Hal ini sejalan dengan keyakinan Albert Einstein bahwa "ilmu tanpa agama buta, sedangkan agama tanpa ilmu itu lumpuh" (Dawkins, 2003: 61).

\section{DAFTAR PUSTAKA}

Abdullah, M.A. (2001). Pengajaran kalam dan teologi di era kemajemukan: Sebuah tinjauan materi dan metode pendidikan agama. Tashwirul Afkar, 11.

Acac, Marybeth T.. (2015). Pancasila: Contemporary application of maqasid al-syari'ah. 
Journal of Indonesian Islam. 9 (1), From DOI: 10.15642/JIIS.2015.9.1.59-78

Al-Hillali, M.T. and Khan, M.M. (2007). The noble Qur'an: English translation of the meanings and comentary. Madina: King Fahd Complex for the Printing of Holy Qur'an.

Bappenas. (2018). Perkembangan ekonomi indonesia dan dunia. Jakarta: Bappenas.

Barnet, T. (1995). Sociology and development. London: Routledge.

Bellah, R.N. (1973). Durkheim on morality and society. Chicago: The University of Chicago Press.

Burhani, A.N.. (2017). Geertz's trilogy of abangan, santri, and priyayi: Controversy and continuity. Journal of Indonesian Islam. 11 (2), from DOI: 10.15642/ JIIS.2017.11.2.329-350.

Connor, S.. (2009). Structure and agency: A debate for community development? In http://www.oxfordjournals.org/cdjc/wpcontent/uploads/2014/08/Stuart_Connor. pdf

Dawkins, R.. (2003). The science of religion. From https://tannerlectures.utah.edu/ documents/a-to-z/d/dawkins_2005.pdf

Foroutan, Naika. (2013). Identity and (muslim) integration in german. Washington DC: Migration Institute Policy.

Galanter, M. (1965). Secularism, east and west. Comparative Studies in Society and History, 7 (2).

Geertz, C. (1973). The Interpretation of cultures. New York: Basic Books, Inc.

Jameson, F.. (2002). A singular modernity: Essay on the ontology of the present. London: Verso.

Koentjaraningrat. (1988). Manusia dan kebudayaan di indonesia. Jakarta: Djambatan.
Ladenburg, T. (2007). Majority rule vs checks and balances, Digital History, from http:// www.digitalhistory.uh.edu/teachers/lesson plans/pdfs/unit2 9.pdf.

Laver, M. and Shepsle, K.A.. (1994). Cabinet ministers and parliamentary government. New York: Cambridge University Press.

Monsma, S.V. (1996). Religious nonprofit organizations and public money: When sacred and secular mix. Maryland: Rowman \& Littlefield Publishers, Inc.

Mufid, A. (2010). Nyleneh itu indah. Yogyakarta: Kutuh.

Mulkhan, A.M. (2001). Humanisasi pendidikan islam. Tashwirul Afkar, 11.

Noy, Chaim. (2017). Moral discourse and argumentation in the public sphere: museums and their visitors. Discourse, Context and Media. 16, from https://doi.org/10.1016/j. dcm.2017.01.005.

Rochmat, S. (2014). The fiqh paradigm for pancasila state: Abdurrahman wahid's thoughts on islam and the republic of indonesia. Al-Jami'ah: Journal of Islamic Studies, 52 (2), 309-329.

Saunders, H.H. (2004). Relational realism: Toward a new political paradigm for security. In Religion and Security, edited by Robert A. Sieple n Dennis R. Hoover. New York: Rowman \& Littlefield Publishers, Inc.

Selva, J.A.N., Domenech, J.L.U. and Gash, H. (2017). Structure and superstructure in complex social Systems. Systems, 5 (28); doi:10.3390/systems5020028.

Wahid, A. (1997). Dimensi kehalusan budi dan rasa. in Anshori Saleh ed. Islam, Negara, dan Demokrasi. Surabaya: Erlangga.

Wahid, A. (2001). Menggerakkan tradisi: Esaiesai pesantren. Yogyakarta: LkiS. 
Waltzer, M. (1994). Thick and thin culture: Moral argument at home and abroad. Notre Dame: University of Notre Dame Press.

Widyastuti, S. (2018). Fostering critical thinking skills through argumentative writing. Cakrawala Pendidikan, 37 (2), 182-189, from https://journal.uny.ac.id/index.php/ cp/article/view/20157/pdf.
Zada, K. (2001), Membebaskan pendidikan islam: dari eksklusivisme menuju inklusivisme dan pluralisme. Tashwirul Afkar, No. 11. 